\title{
Current uses of nanomaterials in biocidal products and treated articles in the EU
}

\author{
Mackevica, Aiga; Revilla Besora, Pau; Brinch, Anna; Hansen, Steffen Foss
}

Published in:

Environmental Science: Nano

Link to article, DOI:

$10.1039 /$ c6en00212a

Publication date:

2016

Document Version

Peer reviewed version

Link back to DTU Orbit

Citation (APA):

Mackevica, A., Revilla Besora, P., Brinch, A., \& Hansen, S. F. (2016). Current uses of nanomaterials in biocidal products and treated articles in the EU. Environmental Science: Nano, 3(5), 1195-1205.

https://doi.org/10.1039/c6en00212a

\section{General rights}

Copyright and moral rights for the publications made accessible in the public portal are retained by the authors and/or other copyright owners and it is a condition of accessing publications that users recognise and abide by the legal requirements associated with these rights.

- Users may download and print one copy of any publication from the public portal for the purpose of private study or research.

- You may not further distribute the material or use it for any profit-making activity or commercial gain

- You may freely distribute the URL identifying the publication in the public portal

If you believe that this document breaches copyright please contact us providing details, and we will remove access to the work immediately and investigate your claim 


\title{
Current uses of nanomaterials in biocidal products and treated articles in the EU
}

\author{
Aiga Mackevica, ${ }^{\mathrm{a}}$ Pau Revilla, ${ }^{\mathrm{a}}$ Anna Brinch, ${ }^{\mathrm{a}}$ Steffen Foss Hansen*a \\ ${ }^{a}$ Department of Environmental Engineering, Technical University of Denmark, Kgs. Lyngby, DK-2800, \\ Denmark \\ *E-mail: sfha@env.dtu.dk
}

\begin{abstract}
Nanomaterials (NMs) are currently being used for a wide variety of products, and a number of them are utilized as biocides due to their antimicrobial or antifungal properties. Little is known to what extent these biocides are available on the market as consumer products. In the EU, Biocidal Product Regulation (BPR) is laying out a list of requirements that manufacturers of biocidal products have to comply with before they can place their products on the market. It is not entirely clear which commercially available articles in the EU that have been treated with or incorporate NMs to provide biocidal properties to the product. To obtain an insight into what biocidal products are on the EU market, we used The Nanodatabase (nanodb.dk) for analyzing which NMs are being used and what product categories they represent. In this paper, we are addressing the issue of current uses of NMs in biocidal products and discussing how they are currently regulated under the BPR. Even though BPR already entails nanospecific provisions, correct labelling of biocidal products containing NMs is virtually non-existent. By using The Nanodatabase it was possible to identify 88 biocidal products containing NMs available on the EU market, none of which had the specific labelling required by BPR. The analysis of biocidal products pinpoints the challenges and limitations for obtaining a reasonable overview of the current uses of NMs in biocidal products as defined in the BPR.
\end{abstract}




\section{Introduction}

Many nanomaterials (NMs) are used in consumer products due to their biocidal activity, e.g. the antibacterial properties of nanosilver and nanocopper are exploited in various products such as antifouling paints, cleaning products, socks, toothbrushes, and many others.

Biocides are chemicals, which are used to control and suppress the growth of unwanted organisms that are harmful to human or animal health, or damaging to human activities. ${ }^{1}$ Metals have been utilized for their antimicrobial properties for centuries ${ }^{2}$ and these properties may be enhanced when the size of the material is reduced to the nanoscale, ${ }^{3}$ because that provides greater reactivity when compared to larger particles. ${ }^{4}$

In 2013, the Biocidal Product Regulation (BPR) went into force in Europe, and the BPR sets out very specific requirements for biocidal products and treated articles that producers have to comply with before they can place their products on the market. When it comes to nanomaterials, these requirements include having to prepare a specific risk assessment for the nanomaterial in question in order to get an authorization for a biocidal product that contains nanomaterials. Nano-specific BPR requirements are needed to better regulate the nanomaterials in consumer products and make sure they are safe before they reach the market.

Very little is known to what extent nanomaterials are used in biocidal products and in treated articles. In order to address this knowledge gap, we analyzed the current list of approved active substances within the BPR for substances that might potentially be in nanoforms as well as the list of substances that are currently undergoing evaluation and that have not yet been approved. Furthermore, in order to map the use of nanomaterials in treated articles, we used The Nanodatabase ${ }^{5}$, which is an European database containing more than 2,300 consumer products claimed to contain nanomaterials and/or to be based on nanomaterials, to identify biocidal products and thereby investigate the current uses of nanomaterials for biocidal purposes in consumer products.

In the following we will first provide a short overview of the BPR and the legislation that 
preceded it, namely the Biocidal Product Directive (BPD). Then we introduce the nanospecific provisions in the BPR with a specific focus on active substances, biocidal products and treated articles, which is followed by a discussion about the list of approved active substances as well as the list of existing active substances to be assessed under BPR, focusing on substances that either have been identified as nanomaterials or that might be nanomaterials. Finally, we present our analysis of biocidal products and treated articles currently listed in The Nanodatabase and pinpoint the challenges and limitations that currently hinder us for obtaining a full overview of the current uses of nanomaterials in biocidal products and treated articles as defined in the BPR.

\section{The Biocidal Product Regulation}

In 1993 the European Commission expressed the need for a legislation to regulate biocidal products on the European market by proposing the first legislative proposal on the subject. ${ }^{6}$ Five years later the Directive concerning the placing of biocidal products on the market (Directive 98/8/EC) (BPD) was adopted. ${ }^{7}$ It was later reported that the directive had several weaknesses including the lack of provisions on nanomaterials, ${ }^{8}$ and in order to address these and improve and update different elements of the Directive, the Commission proposed a new regulation; namely the European Biocidal Product Regulation (Regulation (EU) No $528 / 2012$ ) (BPR), ${ }^{9}$ which came into force in September 2013. The aim of the regulation is to improve the functioning of the internal market for biocidal products in the EU and at the same time to ensure a high level of protection for humans, animals and the environment. ${ }^{10}$ This means that all biocidal product manufacturers and importers must eventually seek authorization according to the procedures described in the BPR before placing a biocidal product on the European market.

\section{1.. Biocidal products}

In the BPR a biocidal product is defined as "any substance or mixture, in the form in which it is 
supplied to the user, consisting of, containing or generating one or more active substances, with the intention of destroying, deterring, rendering harmless, preventing the action of, or otherwise exerting a controlling effect on, any harmful organism by any means other than mere physical or mechanical action" (Art. $3,(a)) .{ }^{10}$ Substances or mixtures with biocidal activity, that are generated from a substance or mixture that do not themselves fall under the definition stated above (i.e. so-called in-situ generated substances) as well as treated articles with a primary biocidal function, are also considered as biocidal products according to the BPR. ${ }^{10}$ As seen from the definition, the main defining constituent of a biocidal product is the active substance, which again is defined as "a substance or a microorganism that has an action on or against harmful organisms" ${ }^{10}$ Active substances are separated into existing active substances and new active substances, which are substances that were placed on the market as part of a biocidal product by May 14, 2000 and substances, which were not on the market at that time, respectively. In order for a manufacturer to obtain authorization for a biocidal product through the BPR, two separate dossiers must be submitted: one for the active substance to be approved and one for the biocidal product (Art. 6). ${ }^{10}$ An approval of an active substance is restricted to a given biocidal product type (PT) (Art. 4), ${ }^{10}$ which means that if a manufacturer wishes to use an active substance in several different product types, then applications must be submitted for each active substance/product type combination within 2 years of the opinion on the approval of the active substance. See Table 1 for a list of the different product types under the BPR.

Table 1: Different product types (PT) under the BPR, adapted from ECHA ${ }^{11}$.

\begin{tabular}{|c|c|c|}
\hline Number & Product type & Description \\
\hline \multicolumn{3}{|c|}{$\begin{array}{l}\text { These product types exclude cleaning products that are not intended to have a biocidal effect, including washing liquids, powders } \\
\text { and similar products. }\end{array}$} \\
\hline PT 1 & Human hygiene & $\begin{array}{l}\text { Products in this group are biocidal products used for human hygiene purposes, applied on or in } \\
\text { contact with human skin or scalps for the primary purpose of disinfecting the skin or scalp. }\end{array}$ \\
\hline PT 2 & $\begin{array}{l}\text { Disinfectants and } \\
\text { algaecides not } \\
\text { intended for } \\
\text { direct application }\end{array}$ & $\begin{array}{l}\text { Used for the disinfection of surfaces, materials, equipment and furniture which are not used for } \\
\text { direct contact with food or feeding stuffs. Usage areas include, inter alia, swimming pools, } \\
\text { aquariums, bathing and other waters; air conditioning systems; and walls and floors in private, } \\
\text { public, and industrial areas and in other areas for professional activities. }\end{array}$ \\
\hline
\end{tabular}




\begin{tabular}{|c|c|c|}
\hline & $\begin{array}{l}\text { to humans or } \\
\text { animals }\end{array}$ & $\begin{array}{l}\text { Used for disinfection of air, water not used for human or animal consumption, chemical toilets, } \\
\text { waste water, hospital waste and soil. } \\
\text { Used as algaecides for treatment of swimming pools, aquariums and other waters and for } \\
\text { remedial treatment of construction materials. } \\
\text { Used to be incorporated in textiles, tissues, masks, paints and other articles or materials with } \\
\text { the purpose of producing treated articles with disinfecting properties. }\end{array}$ \\
\hline PT 3 & $\begin{array}{l}\text { Veterinary } \\
\text { hygiene }\end{array}$ & $\begin{array}{l}\text { Used for veterinary hygiene purposes such as disinfectants, disinfecting soaps, oral or corporal } \\
\text { hygiene products or with anti-microbial function. } \\
\text { Used to disinfect the materials and surfaces associated with the housing or transportation of } \\
\text { animals. }\end{array}$ \\
\hline PT 4 & $\begin{array}{l}\text { Food and feed } \\
\text { area }\end{array}$ & $\begin{array}{l}\text { Used for the disinfection of equipment, containers, consumption utensils, surfaces or pipework } \\
\text { associated with the production, transport, storage or consumption of food or feed (including } \\
\text { drinking water) for humans and animals. } \\
\text { Used to impregnate materials which may enter into contact with food. }\end{array}$ \\
\hline PT 5 & Drinking water & Used for the disinfection of drinking water for both humans and animals. \\
\hline & \multicolumn{2}{|c|}{ Unless otherwise stated these product-types include only products to prevent microbial and algal development. } \\
\hline PT 6 & $\begin{array}{l}\text { Preservatives for } \\
\text { products during } \\
\text { storage }\end{array}$ & $\begin{array}{l}\text { Used for the preservation of manufactured products, other than foodstuffs, feeding stuffs, } \\
\text { cosmetics or medicinal products or medical devices by the control of microbial deterioration to } \\
\text { ensure their shelf life. } \\
\text { Used as preservatives for the storage or use of rodenticide, insecticide or other baits. }\end{array}$ \\
\hline PT 7 & $\begin{array}{l}\text { Film } \\
\text { preservatives }\end{array}$ & $\begin{array}{l}\text { Used for the preservation of films or coatings by the control of microbial deterioration or algal } \\
\text { growth in order to protect the initial properties of the surface of materials or objects such as } \\
\text { paints, plastics, sealants, wall adhesives, binders, papers, art works. }\end{array}$ \\
\hline PT 8 & $\begin{array}{l}\text { Wood } \\
\text { preservatives }\end{array}$ & $\begin{array}{l}\text { Used for the preservation of wood, from and including the saw-mill stage, or wood products by } \\
\text { the control of wood-destroying or wood-disfiguring organisms, including insects. This product } \\
\text { type includes both preventive and curative products. }\end{array}$ \\
\hline PT 9 & $\begin{array}{l}\text { Fibre, leather, } \\
\text { rubber and } \\
\text { polymerised } \\
\text { materials } \\
\text { preservatives }\end{array}$ & $\begin{array}{l}\text { Used for the preservation of fibrous or polymerised materials, such as leather, rubber or paper } \\
\text { or textile products by the control of microbiological deterioration. } \\
\text { This product-type includes biocidal products which antagonise the settlement of micro- } \\
\text { organisms on the surface of materials and therefore hamper or prevent the development of } \\
\text { odour and/or offer other kinds of benefits. }\end{array}$ \\
\hline PT 10 & $\begin{array}{l}\text { Construction } \\
\text { material } \\
\text { preservatives }\end{array}$ & $\begin{array}{l}\text { Used for the preservation of masonry, composite materials, or other construction materials } \\
\text { other than wood by the control of microbiological and algal attack. }\end{array}$ \\
\hline PT 11 & $\begin{array}{l}\text { Preservatives for } \\
\text { liquid-cooling } \\
\text { and processing } \\
\text { systems }\end{array}$ & $\begin{array}{l}\text { Used for the preservation of water or other liquids used in cooling and processing systems by } \\
\text { the control of harmful organisms such as microbes, algae and mussels. } \\
\text { Products used for the disinfection of drinking water or of water for swimming pools are not } \\
\text { included in this product-type. }\end{array}$ \\
\hline PT 12 & Slimicides & $\begin{array}{l}\text { Used for the prevention or control of slime growth on materials, equipment and structures, } \\
\text { used in industrial processes, e.g. on wood and paper pulp, porous sand strata in oil extraction. }\end{array}$ \\
\hline PT 13 & $\begin{array}{l}\text { Working or } \\
\text { cutting fluid } \\
\text { preservatives }\end{array}$ & $\begin{array}{l}\text { Products to control microbial deterioration in fluids used for working or cutting metal, glass or } \\
\text { other materials. }\end{array}$ \\
\hline & & Main group 3: Pest control \\
\hline
\end{tabular}




\begin{tabular}{|c|c|c|}
\hline PT 14 & Rodenticides & Used for the control of mice, rats or other rodents, by means other than repulsion or attraction. \\
\hline PT 15 & Avicides & Used for the control of birds, by means other than repulsion or attraction. \\
\hline PT 16 & $\begin{array}{l}\text { Molluscicides, } \\
\text { vermicides and } \\
\text { products to } \\
\text { control other } \\
\text { invertebrates }\end{array}$ & $\begin{array}{l}\text { Used for the control of molluscs, worms and invertebrates not covered by other product types, } \\
\text { by means other than repulsion or attraction. }\end{array}$ \\
\hline PT 17 & Piscicides & Used for the control of fish, by means other than repulsion or attraction. \\
\hline PT 18 & $\begin{array}{l}\text { Insecticides, } \\
\text { acaricides and } \\
\text { products to } \\
\text { control other } \\
\text { arthropods }\end{array}$ & $\begin{array}{l}\text { Used for the control of arthropods (e.g. insects, arachnids and crustaceans), by means other } \\
\text { than repulsion or attraction. }\end{array}$ \\
\hline PT 19 & $\begin{array}{l}\text { Repellents and } \\
\text { attractants }\end{array}$ & $\begin{array}{l}\text { Used to control harmful organisms (invertebrates such as fleas, vertebrates such as birds, fish, } \\
\text { rodents), by repelling or attracting, including those that are used for human or veterinary } \\
\text { hygiene either directly on the skin or indirectly in the environment of humans or animals. }\end{array}$ \\
\hline PT 20 & $\begin{array}{l}\text { Control of other } \\
\text { vertebrates }\end{array}$ & $\begin{array}{l}\text { Used for the control of vertebrates other than those already covered by the other product types } \\
\text { of this main group, by means other than repulsion or attraction. }\end{array}$ \\
\hline \multicolumn{3}{|r|}{ Main group 4: Other biocidal products } \\
\hline PT 21 & $\begin{array}{l}\text { Antifouling } \\
\text { products }\end{array}$ & $\begin{array}{l}\text { Used to control the growth and settlement of fouling organisms (microbes and higher forms of } \\
\text { plant or animal species) on vessels, aquaculture equipment or other structures used in water. }\end{array}$ \\
\hline PT 22 & $\begin{array}{l}\text { Embalming and } \\
\text { taxidermist fluids }\end{array}$ & Used for the disinfection and preservation of human or animal corpses, or parts thereof. \\
\hline
\end{tabular}

The dossier for obtaining approval for the active substance must contain information on the following:

- the applicant (i.e. the manufacturer or the importer),

- the identity and physico-chemical properties of the substance,

- physical hazards and respective characteristics,

- method of detection and identification,

- effectiveness against target organisms,

- intended uses and exposure,

- toxicological profile for humans and animals,

- ecotoxicity studies,

- environmental fate and behaviour, 
- measures necessary to protect humans, animals and the environment,

- information on classification, labelling and packaging.

The dossier requirements for the biocidal products are similar. ${ }^{12}$ The assessment of the submitted dossiers is performed by the evaluating competent authority, who has to prepare a draft Assessment Report (AR). The applicant then has 30 days to comment on the report, and the application is subsequently handed over to the Biocidal Products Committee under the European Chemicals Agency (ECHA) for their opinion on the draft AR. The AR is finalized under the Biocidal Products Committee from which a final decision on approval is made by the Commission and the Standing Committee on Biocidal Products (Art. 8 \& 9). ${ }^{10}$ Once an active substance is approved, it will appear on the Union list of approved active substances for biocidal products (the "positive list"), which is available on the European Commission's website (Art. 9, (2)). ${ }^{10}$ The list also specifies the product type for which the active substance is approved. ${ }^{13}$ It should be noted that the review of existing active substances is a long process and not due for completion until 31 Dec $2024^{14}$. Step two is to submit a product dossier within 2 years of the opinion of the active substance and get the biocidal product authorized, which can be achieved in several different ways: through a simplified authorization, national authorization, mutual recognition, union authorization or though the concept of product families. ${ }^{10}$

\subsection{Treated Articles}

Under the BPR a 'treated article' is defined as any substance, mixture or article, which has been treated with, or intentionally incorporates, one or more biocidal products. Treated articles include such products as antibacterial socks, t-shirts, food contact materials and many others. However, it should be noted that if a treated article has a primary biocidal function, it has to be considered a biocidal product (Art 3). After 1 September 2016, treated articles should not be placed on the market unless all active substances contained in the biocidal products with which they were treated or which they incorporate are approved in 
accordance with the BPR (Article 58). In case a claim is made by the manufacturer of the treated article regarding its biocidal properties or the approval of the active substance(s) is associated with specific conditions, the treated article shall have a label that provides:

- a statement that the treated article incorporates biocidal products;

- where substantiated, the biocidal property attributed to the treated article e.g. antimicrobial;

- the name of all active substances contained in the biocidal products;

- if applicable, the name of all nanomaterials contained in the biocidal products, followed by the word 'nano' in brackets;

- any relevant instructions for use, including any precautions to be taken, if this is necessary to protect humans, animals and the environment.

The labelling shall be clearly visible, easily legible and appropriately durable (Article 58). Then labelling shall be printed either on the packaging, on the instructions for use or on the warranty (Article 58) and Member States shall make the necessary arrangements for the monitoring of biocidal products and treated articles which have been placed on the market to establish whether they comply with the requirements of this Regulation (Article 65). ${ }^{10}$

The BPR also requires that substantial information related to the treated articles is submitted in order to obtain approval of an active substance. Core data that has to be provided includes likely concentration of the active substance, efficacy data, field of use(s), intended use pattern(s), information on exposure from treated articles including leaching data (either laboratory studies or model data), residues in or on treated articles, application rate and, if appropriate, the final concentration of the biocidal product and active substance in a treated article (see Title I of Annex II on information requirements for active substances). ${ }^{10}$ 


\section{Nano-specific provisions in the BPR}

The BPR is the first European piece of legislation to partly implement the recommended definition of NMs from the European Commission. ${ }^{15}$ The recommended definition defines a NM as "A natural, incidental or manufactured material containing particles, in an unbound state or as an aggregate or as an agglomerate and where, for $50 \%$ or more of the particles in the number size distribution, one or more external dimensions is in the size range $1 \mathrm{~nm}-100 \mathrm{~nm}$. In specific cases and where warranted by concerns for the environment, health, safety or competitiveness the number size distribution threshold of $50 \%$ may be replaced by a threshold between 1 and $50 \%{ }^{\prime \prime}{ }^{15}$ It is important to note that Recital 14 of the Commission Recommendation states that definition should be subject to review in regard to the size distribution threshold of $50 \%$ as well as to whether to include materials with internal structure or surface structure in the nanoscale such as complex nanocomponent nanomaterials e.g nano-porous and nano-composite materials.

Only the first part of the recommended definition is adopted by the BPR, in which a NM is defined as: "A natural or manufactured active substance or non-active substance containing particles, in an unbound state or as an aggregate or as an agglomerate and where, for $50 \%$ or more of the particles in the number size distribution, one or more external dimension is in the size range $1-100 \mathrm{~nm}$ " (Art. 3, (z)). ${ }^{10}$ Thus, the last part of the EU definition of NMs concerning the replacement of the $50 \%$ threshold by a lower one has been omitted in the BPR. The incidentally created NPs are omitted from the BPR definition of NMs as well. The definition of aggregates and agglomerates in the BPR is corresponding to the recommended definitions from the European Commission: "A particle comprising strongly bound or fused particles" and " $A$ collection of weakly bound particles or aggregates where the resulting external surface area is similar to the sum of the surface areas of the individual components", respectively. If a Member State is uncertain whether a substance is a NM, the final decision lays upon the European Commission according to the BPR. It is furthermore stated that the European Commission will have the power to adapt the definition a NM in the light of technical or scientific progress (Art. $3(3 \& 4)) .{ }^{10}$ 
Article 4 of the BPR states that an approval of an active substance does not cover the NM form as well, except in cases where it is explicitly mentioned (Art. 4). ${ }^{10}$ The argument for this provision relies on the fact that NMs are being used as a biocide because of their different properties compared to the bulk form of the same material, and these different properties may also result in different toxicities, which is why NMs require an assessment of their own. In order to obtain an authorization of a biocidal product that contains NMs, a specific risk assessment has to be performed for the NM in question (Art. 19). ${ }^{10}$ Furthermore, due to current lack of adequate risk assessment of NMs, it is not possible to apply for a simplified authorization if the biocidal product contains NMs (Art. 25). ${ }^{10,16}$ The BPR also contains extensive requirements regarding labelling of biocidal products and treated articles. In addition to other information, all biocidal products containing NMs must have a label, stating that the product contains NMs, including the specific related risks of the NM and the word 'nano' in brackets following each reference to the given NM (Art. 69). ${ }^{10}$ For articles treated with a biocidal product containing NMs, labelling with information of the names of all NMs contained in the product, followed by the word 'nano' in brackets, is required (Art. 58). ${ }^{10}$ The specific labelling provisions for these materials were included by the European Parliament due to the lack of knowledge regarding the impact of NMs on health and the environment, and the users of the biocidal products are therefore entitled to be correctly informed via adequate labelling. ${ }^{16}$ Once established on the market, Member States are furthermore obliged to monitor the Biocidal products and treated articles to make sure that they comply with the requirements of the BPR. Every five years each Member State must submit a report to the European Commission, which among other information must include details of the use of NMs in biocidal products and the potential risk thereof (Art. 65). ${ }^{10}$

\section{Nanomaterials and the list of approved active substances}

A company that wishes to use a given nanomaterial in a biocidal product has to obtain the approval, and the granted approval for the active substance must apply to the nanoforms of that active substance, except where explicitly stated otherwise. Hence, the current list of approved substances, and those substances 
being examined under the Review Programme, gives a good indication as to which kinds of nanomaterials might be used in biocidal products in the EU and therefore might be subject to nano-specific BPR requirements. This list currently contains basic copper carbonate, boric oxide, copper (II) oxide and copper hydroxide, which are commercially available in the nanoform (see, for instance, the Nanowerk's Nanomaterials database ${ }^{17}$ ). For most of these materials, it is unknown whether the nanoform is being sold as a biocidal ingredient in Europe, although some are clearly being marketed as such, such as the "biocidal copper carbonate nanoparticles" sold by the German company nanoSaar.

So far, only one type of NM has been approved as an active substance, namely synthetic amorphous silicone dioxide (SAS). SAS is approved as an active substance in product type 18 (insecticides). Although SAS should in theory be evaluated based on the data requirements of the BPD, SAS was in reality also evaluated in the light of the BPR when it comes to nanomaterials. For instance, according to the assessment report, SAS is a NM based on the definition in article $3(\mathrm{z})$ in the $\mathrm{BPR},{ }^{10}$ since it consists of primary particles with a size $<25 \mathrm{~nm}$. However, the data provided by the manufacturer shows that the active substance will be an aggregate of primary particles with a size of 1-6 $\mu \mathrm{m}$. It is therefore stated in the assessment report that the hazard and risk of the individual NPs of silicon dioxide were not evaluated in the dossier, since "Under conditions of normal handling and use, it is considered that aggregates are the smallest stable particles. In this context, data provided by the notifier and literature tend to show that liberation of primary particles and exposure to nano-object (material with one, two or three external dimensions in the nanoscale) is not expected during and after the intended biocidal application considered in this dossier" ${ }^{18}$

Silicon dioxide (as a nanomaterial formed by aggregates and agglomerates) and silver adsorbed on silicon dioxide (HeiQ AGS-20) are currently under review for PT 18 and PT 9, respectively. ${ }^{19,20}$ For HeiQ AGS20 , which consists of stable 1-50 $\mu \mathrm{m}$ particle aggregates containing primary particles in the nanoscale, the Biocidal Products Committee $(B P C)^{18}$ has expressed the opinion that AGS-20 is to be regarded as the biocidal active substance as it is the result of a combustion synthesis process and not just a simple mixing of 
the two components and that a range for the silver content and silicon dioxide content should be added to further specify the active substance. They furthermore note that AGS-20 meets the definition of a nanomaterial under the BPR as it is a stable aggregate with primary nanoparticles complying with the number size distribution provision in the BPR and that the derogation of complex heterogeneous nanomaterials including nano-composites in recital 14 to Commission Recommendation 2011/696/EU does not apply to AGS-20, since it is a purely particulate materials despite of the fact that it is a composite. While not wanting to express their opinion on a possible nanospecification of AGS-20 prior to the evaluation phase of the active substance, the BPC does refer to the approval of nanoSAS and state that it could be outlined that AGS-20 is a stable aggregate with primary particles in the nanoscale with additional specification of particle size and volume specific surface area. The latter indicates that the SAS evaluation could create precedence when it comes to approval of nanomaterials.

Other assessment reports specifically mention that they do not cover the nano-form of that active substance (i.e. ARs for basic copper (II) carbonate, copper (II) hydroxide and copper (II) oxide). ${ }^{21,22,23}$ The Competent Authority Reports $(\mathrm{CARs})^{24}$ for copper carbonate, copper oxide and copper hydroxidespecifically mention that the nanoforms of these substances are not included in the reports. For instance, for basic copper carbonate, the assessment states that "the applicant is not currently placing nanoforms of basic copper carbonate on the market. Therefore, the submitted dossier and the finalised assessment report don't cover potential nanoforms of this copper compound, should such forms exist." ${ }^{21}$

\section{Nanomaterials and the review programme on existing active substances}

Under the BPD a 10-year review programme was set up with the purpose of systematically examining all active substances already on the market. The outcome of the examination would either be an inclusion of the substance to the list of approved substances (Annex I, IA or IB of the BPD), or no inclusion and thereby a restriction of the marketing and use of the substance. ${ }^{7}$ The review programme on existing active substances initiated under the BPD is continued under the BPR and was expected to be finalized by May 
2014 (Art 89). ${ }^{10}$ In an amendment of the BPR it was decided to extend the review period until 2024 and to differentiate between the deadlines for the different product types. ${ }^{14}$ As stated in Article 86 of the BPR, active substances which were already approved and thereby included in Annex I of the BPD, should be deemed as approved under the BPR as well, and thus automatically included in the positive list (Art. 86). ${ }^{10}$

As introduced above, a number of existing active substances are currently under review. It is, however, not indicated whether any of the active substances included in Annex II of Regulation (EC) $1451 / 2007$ are in nanoform, since NM-specific requirements were not included in the scope of the BPD, nor mentioned in Regulation (EC) 1451/2007. ${ }^{25}$ This results in different issues and uncertainties regarding the legal status of NMs under the BPR and the review programme, as pointed out by both Member States and the nano-industry, and clarification of this is therefore needed. ${ }^{10,26}$

Nevertheless, considering the list of existing active substances that are currently under review, it is clear that at least some of them might be available in the nanoform, for instance, silver, copper, dicopper oxide and silicon dioxide. See Table 2 for substances being examined under the Review Programme that might be available in the nanoform and the Product Types that they have been notified for use in.

Table 2: Substances being examined under the Review Programme ${ }^{27}$ that might be available in the nanoform and the Product Types that they have been notified to be used in.

\begin{tabular}{|l|l|l|l|l|l|l|l|l|l|}
\hline & PT1 & PT2 & PT4 & PT5 & PT7 & PT9 & PT11 & PT18 & PT21 \\
\hline Silver & & $\mathrm{X}$ & $\mathrm{X}$ & $\mathrm{X}$ & & & $\mathrm{X}$ & & \\
\hline Silver phosphate glass & & $\mathrm{X}$ & & & $\mathrm{X}$ & $\mathrm{X}$ & & & \\
\hline Silver-Zinc-Zeolite & & $\mathrm{X}$ & $\mathrm{X}$ & $\mathrm{X}$ & $\mathrm{X}$ & $\mathrm{X}$ & & & \\
\hline Silver copper zeolite & & $\mathrm{X}$ & $\mathrm{X}$ & $\mathrm{X}$ & $\mathrm{X}$ & $\mathrm{X}$ & & & \\
\hline $\begin{array}{l}\text { Silver adsorbed on silicon } \\
\text { dioxide }\end{array}$ & & & & & & $\mathrm{X}$ & & & \\
\hline Silver zeolite & & $\mathrm{X}$ & $\mathrm{X}$ & $\mathrm{X}$ & $\mathrm{X}$ & $\mathrm{X}$ & & & \\
\hline Silicium dioxide & & & & & & & & $\mathrm{X}$ & \\
\hline Dicopper oxide & & & & & & & & & $\mathrm{X}$ \\
\hline Copper & & & & & & & & & $\mathrm{X}$ \\
\hline
\end{tabular}




\section{Active substances and the Nanodatabase}

At this point it is not entirely clear which commercially available articles in the EU have been treated with nanomaterials or incorporate a biocidal form of a nanomaterial. Similarly, it is not clear which biocidal products might be available in commerce. As described above, the BPR contains provisions that apply to active substances, biocidal products and articles, which incorporate a biocidal product or have been treated with a biocidal product. Following approval of the active substance, biocidal products can only contain active substances that have been approved for the specific use in the specific PT and articles can only be treated with active substances, which have been approved in the EU for that specific purpose. The only approved nanoform of an active substance in the BPR currently is silicon dioxide (for PT18), whereas silver adsorbed on silicon is under review (for PT9). However, it is well known that, for instance, nanosilver and nanocopper are used in consumer products because of their biocidal properties. ${ }^{28}$ Since 2012 , we have maintained and updated a European nanoproduct inventory, The Nanodatabase, ${ }^{5}$ in collaboration with the Danish Ecological Council and the Danish Consumer Council. Out of the 2329 products containing nanomaterials, which are estimated to be on the European market, 342 contain nanosilver, 48 contain silicon dioxide, and six contain copper (Figure 1). Most of the products that use biocidal nanomaterials fall into the "health and fitness category" (for example, personal care products and clothing), "home and garden" (cleaning products) or "food and beverages" (food supplements, storage and cooking). Around 100 products contain titanium dioxide, which can be considered as an active substance, but it must be noted that it is also widely used as a pigment.

In about half of all the nanosilver-containing products in The Nanodatabase, the producers make antibacterial or antifungal claims. It is interesting that none of the products in this database seem to have a proper label according to the BPR rules to disclose that they contain nanomaterials including the word "nano" in brackets, following each reference to the given nanomaterial, and which specify the specific related risks. This is the case despite the fact that labelling is a key provision (Article 68$)^{10}$ in the BPR for products marketed after 1 September 2013. 


\section{Biocidal products and treated articles in The Nanodatabase}

The Nanodatabase ${ }^{5}$ contains 88 biocidal products in total, and most of them are representing product types 1 and 2, i.e. disinfectants and algaecides, and human hygiene products, respectively (Figure 2). Such products include disinfecting sprays, air purifiers, cleaning products, biocidal paints and varnishes, etc. The nanomaterials that are the active substances in those biocidal products are primarily silver (46 products), with a few products containing silicon dioxide ( 3 products), and a large fraction of all biocidal products are containing nanomaterial of unknown identity (39 products). If the nanomaterial identity for the biocidal product is unknown, it means that the manufacturer is claiming both the presence of nanomaterials in the product and the biocidal properties of the product.

When it comes to looking at biocidal products in different product categories in The Nanodatabase, it becomes apparent that most of the products fall into "home and garden" category, which is for the most part represented by different cleaning products, detergents and paints, corresponding to product type 2 - disinfectants and algaecides, according to the BPR (Figure 3).

There are 202 nano-enabled treated articles reported in The Nanodatabase in total, and most of them (157) have nanosilver as the active substance (see Figure 4). Other nanomaterials used in treated articles include bamboo charcoal, which is used for such products as air purifiers and textiles, carbon, which is used for water filtration devices, and several products include nano iron, gold and titanium as an active biocidal substance.

The largest fraction of the nano-enabled treated articles (79\%) that are found in The Nanodatabase, fall into "Health and Fitness" category, representing different textiles, personal care items, and food contact materials (Figure 5).

\section{Discussion and recommendations}

The present paper is one of the first studies that address the current uses of nanomaterials in biocidal 
products and treated articles. It describes how nanomaterials are regulated under the BPR and which nanomaterials might be used in biocidal products and treated articles based on the review programme and information about nanoproducts available in The Nanodatabase, 88 of which are considered to be biocidal products.

Outset for our analysis was taken in the List of active substances and the List of substances under the review program. Regarding the List of active substances, it is unclear whether any of the substances might be in the nanoform as defined by the BPR as they might already have been assessed and approved under the BPD. As a consequence, they have automatically been included on the list of approved substances under the BPR not considering that they might be nanomaterials. ${ }^{29}$ In order to avoid confusion, the European Commission has to make it clear that active substances assessed and/or approved under the BPD that are in the nanoforms are not automatically approved under the BPR and therefore have to obtain their own approval and have to be subject to the nanospecific requirements of the BPR.

A number of substances currently included in the review programme, such as silver, could be nanomaterials, but it is lack of clarity regarding the exact form of the active substances assessed and supported by the applicants and currently under review. The Commission has set procedures in motion to contact all participants in the review program in order to obtain information on the exact form of the active substance proposing that substances of which a notification is subsequently submitted to the Commission will be allowed to remain on the market until a decision on their approval has been established. ${ }^{29}$

There are several nanomaterials, e.g. copper, on the List of active substances and the List of substances under the review program where producers and retailers of the nanoforms claim that the nanoforms of the material have biocidal properties despite the fact that the nanoform is specifically mentioned not to be part of the assessment report completed competent authority as part of the approval process. ECHA has called for producers and importers to come forward and sponsor the nanoforms of e.g. copper and deadline for this was 30 October 2015 One notification only has been received for a nanoform of silver. The European Commission is the process of making a non-approval decision which will clarify that 
apart from the nanoform of active substance explicitly mentioned in Annex II of the Review Programme Regulation (EU) No 1062/2014, ${ }^{27}$ no nanomaterial is supported under the review programme. This will again lead to the Commission being able to initiate the modification of the Review Regulation itself and in particular its Annex II so that only includes substances included in the review programme. As a result of this exercise only two nanoform of silver will remain in the review programme. ${ }^{30}$

The success of these modifications is of crucial importance for the overall trustworthiness of the European Commission, ECHA and the BPR that the European Commission and ECHA are able to identify and put claims about biocidal properties to a halt for substances that are sold in the nanoforms, but which are not covered by the Biocidal Products Committee opinions on active substance approval.

At this point it is not entirely clear which commercially available articles in the EU have been treated with nanomaterials or incorporate a biocidal form of a nanomaterial. Similarly, it is not clear which biocidal products might be commercially available. In our analysis of biocidal products and treated articles we took outset in The Nanodatabase and analyzed which nanomateirals were used and what product types the uses would fall under.

In about $50 \%$ of all the nanosilver-containing products, the producers make antibacterial or antifungal claims which means that the product are likely to fall under the provisions of the BPR. However, in the present study it was not possible to determine whether nanomaterials were actually present in the products with claims about "nano" by looking at the labels of the products. It was furthermore not possible to evaluate whether the products claimed to have biocidal properties are actually effective as antimicrobials.

Adequate labelling is a major problem and risks undermining the credibility of the treated article provisions in the BPR. The EU could learn from the nanoMark System implemented by the Industrial Development Bureau, Ministry of Economic Affairs in Taiwan in 2004 for certifying nanoproducts. The system was put in place to enhance the quality and image of products based on nanotechnology and protect consumer's rights while simultaneously promoting the development of a national nanotechnology 
industry. ${ }^{31}$ Specifically, the nanoMark should only be granted to "real nanoProducts" that are considered good enough for a specified level and use in order to avoid confusion and protect the right of consumers while also preventing "bad products from driving out good ones in a market glutted with nano-products of different quality". ${ }^{31,32}$ In order to receive the NanoMark certification and be allowed to wear the NanoMark label, tests have to be completed by qualified and verified laboratories validating the claims made by the manufacturers regarding the particle size and chemical constitution of the nanomaterials in their products and their advertised efficacy. ${ }^{33} 39$ companies and 1490 products have passed the NanoMark certification in the period from 2004 and $2014^{34}$ and in 2012, the NanoMark had 41 NanoMark product verification standards including some that are relevant for the BPR, for instance photocatalytically active anti-bacterial tiles, lamps and coatings and nano silver antibacterial paint for indoor decoration, household decoration textiles, socks, sanitary ceramic ware, plastic toilet seat, plastic toilet tank parts. ${ }^{32,33,35}$ Ten years after implementation, it seems that the nanoMark system has not only helped the companies increase their corporate image and promoted "market sales", but has also allowed companies that participate in the system to increase the selling price of their products by $20 \% \cdot{ }^{36}$ This provides clear evidence that implementing nanospecific certification requirements in the BPR would enhance the overall enterprise competitiveness of the industry while also assisting in gaining consumer trust in the BPR and weed out products that claim to contain nanomaterials and have biocidal properties when they actually do not.

There are a number of tools available to determine the presence of nanomaterials in biocidal products and treated articles, as well as to quantify the amount of the active substance in the product. Ideally the manufacturer should be able to provide necessary information regarding the primary size and total amount of the nanoparticles applied to the certain product, but this information is not always readily available. In the recent years there has been an increasing amount of scientific publications addressing the issue of the presence nanomaterials in consumer products and the uncertainties regarding their safety (e.g. $\left.{ }^{37,38,39}\right)$. To determine the presence of a biocidal substance is not the most challenging part, however, to verify that the substance occurs in its nanoform is a much more complex task to accomplish. Depending on 
what the product is - solid, liquid, or aerosol - there are different set of methods that can be applied to find NMs in the product. A recent review by Laborda et al. ${ }^{40}$ has compiled and described the experimental studies published to date that have attempted to determine the presence of NMs in different types of consumer products including several items with antibacterial and disinfection claims and properties, highlighting also a variety of analytical tools and sample preparation methods that can be used for quantification and characterization. For example, when it comes to such liquid samples as sunscreens, which most commonly use $\mathrm{TiO}_{2}$ or $\mathrm{ZnO}$ nanoparticles, it is possible to use electron microscopy (EM) in combination with electron dispersive X-ray spectroscopy (EDS) to find and identify the nanoparticles. ${ }^{41}$ Alternatively, as one study has illustrated, single particle inductively coupled plasma mass spectrometry (spICP-MS) is also a powerful tool to both identify and quantify the nanoparticle content in such samples, as well as provide the size distribution of the particles in the sunscreen. ${ }^{42}$ The spICP-MS method as described by Dan et al. ${ }^{42}$ could also be applicable for a large number of personal care products that have to be tested for their NM content. Similar output is also possible with other tools such as asymmetric flow field flow fractionation (AF4) combined with ICP-MS or UV-Vis. ${ }^{43,44}$ Other products that have been addressed in the literature and experimentally investigated include various dietary supplements that contain Ag nanoparticles, ${ }^{45,46}$ disinfectant sprays with $\mathrm{Ag}$ or $\mathrm{ZnO} \mathrm{NP}{ }^{47,48}$ and different food products such as e.g. chicken meat with $\mathrm{Ag} .{ }^{49,50}$ So in general, even when it comes to analyzing NMs in very complex matrices and different types of materials, there are methods available to tackle the nanomaterial characterization and quantification issues. However, many of the methods require extensive sample preparation for e.g. NM extraction and accurate nanoparticle characterization, and many of the analytical tools are costly and therefore are only available in specialized research labs. Therefore, it would be highly beneficial if manufacturers can provide necessary information about the pristine particles that are applied in the products, including the sizes and the quantity of the particles applied, as well as noting the location of the particles (suspended in liquid/solid, attached to the surface etc.). This would aid legislators, researchers and consumers to better understand the properties of the product. 


\section{Conclusions}

The number of nano-enabled biocidal products and treated articles is increasing on the European market, according to the information available on The Nanodatabase. ${ }^{5}$ However, even though they advertise NM content, most of the products do not have specific labelling as required by BPR. Moreover, most of the utilized NMs are not yet approved by the BPR, illustrating the need for manufacturers to provide the specific information necessary to approve and register the substances according to the procedures highlighted in the BPR. It is of utmost importance for European Commission and European Chemical Agency to take steps to enforce their legislation and ensure proper labelling of biocidal products and treated articles that contain NMs.

\section{Acknowledgements}

This work is part of the project ENVNANO (Environmental Effects and Risk Evaluation of Engineered Nanoparticles) supported by the European Research Council (grant no. 281579). This work has also received funding from the European Union's Seventh Framework Programme [FP7/2007-2013] under ECGA no. 604305 'SUN'.

\section{Reference list}

1. European Commission, Biocides - Introduction. http://ec.europa.eu/environment/chemicals/biocides/index en.htm (Accessed June 2016).

2. G. Borkow and J. Gabbay, Current Chemical Biology, 2009, 3(3), 272-278.

3. C. Gunawan, W.Y. Teoh, C.P. Marquis, and R. Amal, ACS Nano, 2011, 5(9), pp.7214-7225.

4. M. Farré, K. Gajda-Schrantz, L. Kantiani, and D. Barceló, Analytical and Bioanalytical Chemistry, 2009, 393(1), 81-95.

5. The Nanodatabase, http://nanodb.dk (Accessed June 2016).

6. European Commission, Commsion Proposal for a Council Directive concerning the placing of biocidal products on the market (93/C 239/03). Official Journal of the European Union, 1993, 3-40. 
7. European Parliament and Council, Directive 98/8/EC of the European Parliament and of the Council of 16 February 1998 concerning the placing of biocidal products on the market. Official Journal of the European Union, 1998, L 123, 1-63.

8. M.T. Reinsborough and G. Sullivan, European Journal of Law and Technology, 2011, 2(3).

9. European Commission, Proposal for a Regulation of the European Parliament and of the Council concerning the placing on the market and use of biocidal products. COM, 2009, 267 Final.

10. European Parliament and Council, Regulation (EU) No 528/2012 of the European Parliament and of the Council of 22 May 2012 concerning the making available on the market and use of biocidal products. Official Journal of the European Union, 2012, L 167, 1-123.

11. ECHA, Biocidal Products Regulation: Product types. http://echa.europa.eu/regulations/biocidalproducts-regulation/product-types (Accessed June 2016).

12. European Chemicals Agency, Guidance on information requirements. Guidance on Regulation (EU) No $528 / 2012$ Concerning the Making Available on the Market and Use of Biocidal Product (BPR) Version $1.0,2013$.

13. European Commission, List of approved substances. http://ec.europa.eu/environment/chemicals/biocides/active-substances/approvedsubstances en.htm (Accessed June 2016).

14. European Commission, Commission Delegated Regulation (EU) No 736/2013 amending Regulation (EU) No 528/2012 of the European Parliament and of the Council as regards the duration of the work programme for examination of existing biocidal active substances. Official Journal of the European Union, 2013, L 204/25.

15. European Commission, Commission Recommendation of 18 October 2011 on the definition of nanomaterial. Official Journal of the European Union, 2011, L 275, 38-40.

16. European Parliament, Recommendation for second reading on the Council position at first reading with a view to the adoption of a regulation of the European Parliament and of the Council concerning the making available on the market and use of biocidal products 05032/2/2011. Committee on the Environment, Public Health and Food Safety, 2011.

17. Nanowerk, Nanomaterials Database. http://www.nanowerk.com/nanomaterial-database.php (Accessed June 2016).

18. Biocidal Products Committee (BPC), 2014. Opinion on a request according to Article $75(1)(\mathrm{g})$ of Regulation (EU) No 528/2012 HeiQ AGS-20 ECHA/BPC/ 001/ 2014. http://echa.europa.eu/documents/10162/21680461/bpc opinion heiq ags-20 en.pdf (Accessed June 2016).

19. ECHA, Silicon dioxide (as a nanomaterial formed by aggregates and agglomerates). http://dissemination.echa.europa.eu/Biocides/factsheet?id=1449-18. Accessed 14-03-2016 (Accessed June 2016).

20. ECHA, Silver adsorbed on silicon dioxide. http://dissemination.echa.europa.eu/Biocides/factsheet?id=1448-09 (Accessed June 2016). 
21. Standing Committee on Biocidal Products, Assessment Report Basic copper carbonate Product-type 8 (Wood preservatives) September 2011, France.

http://dissemination.echa.europa.eu/Biocides/ActiveSubstances/0006-08/0006-

08 Assessment Report.pdf (Accessed June 2016).

22. Standing Committee on Biocidal Products, Assessment ReportCopper (II)HydroxideProduct-type 8 (Wood preservatives) September 2011 France.

http://dissemination.echa.europa.eu/Biocides/ActiveSubstances/0016-08/0016-

08 Assessment Report.pdf (Accessed June 2016).

23. Standing Committee on Biocidal Products, Assessment ReportCopper (II) oxide Product-type 8 (Wood preservatives) September 2011 France.

http://dissemination.echa.europa.eu/Biocides/ActiveSubstances/0017-08/0017-

08 Assessment Report.pdf (Accessed June 2016).

24. ECHA, Biocidal Active Substances. http://echa.europa.eu/web/guest/information-onchemicals/biocidal-active-substances (Accessed June 2016).

25. European Commission, Commission Regulation (EC) No 1451/2007 on the second phase of the 10-year work programme referred to in Article 16(2) of Directive 98/8/EC of the European Parliament and of the Council concerning the placing of biocidal products on the market. Official Journal of the European Union, 2007. http://data.europa.eu/eli/reg/2007/1451/oj (Accessed June 2016).

26. Nanotechnology Industries Association (NIA), Nanomaterials and the EU biocides legislation (CAMay12-Doc.6.2.g.i), 2012.

27. European Commission, Commission Delegated Regulation (EU) No 1062/2014 of 4 August 2014 on the work programme for the systematic examination of all existing active substances contained in biocidal products referred to in Regulation (EU) No 528/2012 of the European Parliament and of the Council Text with EEA relevance, Official Journal of the European Union, 2014. http://eur-lex.europa.eu/legalcontent/EN/TXT/PDF/?uri=CELEX:32014R1062\&from=EN (Accessed June 2016).

28. O. Bondarenko, K. Juganson, A. Ivask, K. Kasemets, M. Mortimer, and A. Kahru, Archives of Toxicology, 2013, 87, 1181-200.

29. European Commission, Biocides and nanomaterials (CA-May13-Doc.5.1.g), 2013. https://chemicalwatch.com/downloads/CA-Dec12-Doc.5.1.pdf(Accessed June 2016).

30. Communication from the Commission services.

31. Taiwan Nanotechnology Industry Development Association, Nano Mark, 2007. http://www.tanida.org.tw/Eng/Mark/(Accessed June 2016).

32. NanoMark, Product Information. Industrial Development Bureau, Ministry of Economic Affairs, Taiwan. http://www.nanomark.org.tw/Eng/Product/product.asp (Accessed June 2016).

33. A. Hsu, 2006. Taiwanese government launches nanoproduct certification system. Taiwan Journal. February 17, 2006. http://www.taiwantoday.tw/fp.asp?xltem=23198\&CtNode=451 (Accessed June 2016). 
34. V. Amenta, K. Aschberger, M. Arena, H. Bouwmeester, F.B. Moniz, P. Brandhoff, S. Gottardo, H.J. Marvin, A. Mech, L.Q. Pesudo, and H. Rauscher, Regulatory Toxicology and Pharmacology, 2015, 73(1), 463-476.

35. Chemical watch, 2012. Taiwan issues three new verification standards for nano products. Taiwan, Classification, Nanomaterials https://chemicalwatch.com/asiahub/12210/taiwan-issues-three-newverification-standards-for-nano-products (Accessed June 2016).

36. H. Jin and L. Liu, 2014. Asia Nano Forum Newsletter (Issue No. 25). ANF Secretariat, Singapore. http://www.asia-anf.org/admin/upload/files/general/News433_1.pdf (Accessed June 2016).

37. C.A. Impellitteri, T.M. Tolaymat, and K.G. Scheckel, Journal of environmental quality, 2009, 38(4), 152830.

38. T. Benn, B. Cavanagh, K. Hristovski, J.D. Posner, and P. Westerhoff, Journal of environmental quality, 2010, 39(6), 1875-82.

39. J. Farkas, H. Peter, P. Christian, J.A. Urrea, M. Hassellöv, J. Tuoriniemi, S. Gustafsson, E. Olsson, K. Hylland, and K.V. Thomas, Environment international, 2011, 31;37(6), 1057-62.

40. F. Laborda, E. Bolea, G. Cepriá, M.T. Gómez, M.S. Jiménez, J. Pérez-Arantegui, and J.R. Castillo, Analytica chimica acta. 2016, 904, 10-32.

41. Z.A. Lewicka, A.F. Benedetto, D.N. Benoit, W.W. Yu, J.D. Fortner, V.L. Colvin, J. Nanopart. Res., 2011, 13, 3607-3617.

42. Y. Dan, H. Shi, C. Stephan, and X. Liang, Microchemical Journal, 2015, 22, 119-26.

43. V. Nischwitz and H. Goenaga-Infante, J. Anal. At. Spectrom., 2012, 27, 1084-1092.

44. C. Contado and A. Pagnoni, Anal. Chem., 2008, 80, 7594-7608.

45. R.B. Reed, J.J. Faust, Y. Yang, K. Doudrick, D.G. Capco, K. Hristovski, and P. Westerhoff, ACS Sustain. Chem. Eng., 2014, 1616-1624.

46. K. Ramos, L. Ramos, C. Cámara, M.M. Gómez-Gómez, J. Chromatogr. A, 2014, 1371, 227-236.

47. H. Hagendorfer, C. Lorenz, R. Kaegi, B. Sinnet, R. Gehrig, N.V. Goetz, M. Scheringer, C. Ludwig, and A. Ulrich, J. Nanopart. Res., 2010, 12, 2481-2494.

48. C. Lorenz, H. Hagendorfer, N. von Goetz, R. Kaegi, R. Gehrig, A. Ulrich, M. Scheringer, and K. Hungerbühler, J. Nanopart. Res., 2011, 13, 3377-3391.

49. K. Loeschner, J. Navratilova, C. Købler, K. Mølhave, S. Wagner, F. von der Kammer, and E.H. Larsen, Anal. Bioanal. Chem., 2013, 405, 8185-8195.

50. K. Loeschner, J. Navratilova, R. Grombe, T.P.J. Linsinger, C. Købler, K. Mølhave, and E.H. Larsen, Food Chem., 2015, 181, 78-84. 